\title{
A gênese histórica da fenomenologia hermenêutica de Martin Heidegger
}

\author{
The historical genesis of Martin Heidegger's \\ hermeneutic phenomenology
}

\author{
Renato Kirchner \\ Pontifícia Universidade Católica de Campinas \\ renatokirchneroo@gmail.com \\ Crisóstomo Lima do Nascimento \\ Universidade Federal Fluminense \\ crisostomoln@gmail.com
}

\section{Resumo}

O presente artigo tem como objetivo principal compreender de que maneira autores como Hume e Kant, Schleiermacher e Dilthey, Ranke e Droysen, Hegel e Husserl estiveram no horizonte das investigações heideggerianas antes dos anos 30 do século XX, de modo que seja possível visualizar em que medida a fenomenologia hermenêutica de Martin Heidegger possui uma gênese histórica toda peculiar. Além das constantes referências às obras de Martin Heidegger, a tarefa aqui assumida não poderia prescindir do confronto com comentadores e estudiosos diversos. Neste intuito, foram percorridos os seguintes estágios: 1. Demarcando as origens da fenomenologia hermenêutica; 2 . Schleiermacher e Dilthey: principais influências da tradição hermenêutica; 3. A fenomenologia de Husserl como fonte de inspiração e superação; 4. Heidegger: os passos decisivos em vista da fenomenologia hermenêutica.

Palavras-chave: Fenomenologia hermenêutica. Questão pelo sentido do ser. Analítica existencial. Martin Heidegger.

\section{Abstract}

The main objective of this article is to understand how authors such as Hume and Kant, Schleiermacher and Dilthey, Ranke and Droysen, Hegel and Husserl were on the horizon of Heidegger's investigations before the 30 s of the $20^{\text {th }}$ century, so that it is possible to visualize where far as Martin Heidegger's hermeneutic phenomenology is concerned and it has a peculiar historical genesis. In addition to the constant references to the works of Martin Heidegger, the task undertaken here could not do without the confrontation with various commentators and scholars. With this in mind, the following stages were covered: 1. Demarcating the origins of hermeneutic phenomenology; 2. Schleiermacher and Dilthey: main influences of the hermeneutic tradition; 3. Husserl's phenomenology as a source of inspiration and overcoming; 4. Heidegger: decisive steps in view of hermeneutic phenomenology. 
Keywords: Hermeneutic Phenomenology. Question for the sense of being. Existential analytics. Martin Heidegger.

\section{Introdução}

Uma tácita circularidade semântica usualmente evocada de forma intuitiva acompanha a experiência do pensamento quando este se direciona à palavra "ser", tendo como consequência o decorrente abandono de uma sustentação de modo mais vigoroso de uma apropriação ontológica. O demorar-se junto a tal questão, tanto relativo ao modo de ser das coisas em geral quanto do próprio homem, a partir do qual a questão tem a possibilidade de ser sustentada, é causa de frequente desconforto e estranhamento devido ao seu caráter aparentemente desnecessário e expressamente tautológico. Desnecessário, porque não nos costuma parecer muito significativo o investimento de tempo e energias na compreensão mais rigorosa de algo que, contraditoriamente, não nos impede de continuarmos fazendo uso a cada momento de nossas vidas, sem, aparentemente, maiores implicações. Tautológico, na medida em que pensar nos impele a recorrer a palavras, noções e sentidos que, ao explicarem o primeiro, já carregam consigo uma pré-compreensão velada do que aquele significaria e, portanto, já estaríamos lançando mão daquilo que desejamos utilizar para explicá-lo. Temos aqui, pois, a circularidade tácita pré-compreensiva do ser.

O filósofo alemão Martin Heidegger tomou assim a questão do ser como a mais fundamental de todas e, ao assumir a tarefa de questionamento sobre o seu sentido, colocou também em questão o próprio ser deste ente que nós mesmos somos - historicamente denominado homem -, assim como problematizou temas tidos como cruciais para sua tematização mais rigorosa como existência, historicidade, temporalidade, realidade e verdade. Com isso, Heidegger nos oferece elementos para uma investigação rigorosa sobre nós mesmos, os sentidos que atribuímos às coisas no cotidiano e, dentre elas, nossas próprias noções de "homem", "vida" e "mundo". O filósofo reconhece a herança cartesiana que circunscreve a modernidade e que "converte" a noção de homem na de sujeito, sendo a sua dimensão imaterial (res cogitans), pensamento, o modo como este sujeito re-apresenta para si aquilo que se lhe opõe e que dele se distingue, isto é, toda a sua "exterioridade" e a realidade em sua dinâmica própria. 
Assim, o horizonte da subjetividade-objetividade é a perspectiva a partir da qual a verdade do homem e do mundo se dá a ver e conhecer. Neste sentido, tanto no âmbito das ciências do homem quanto nas relações de sentidos mais basais do cotidiano, não nos furtamos a herdar e operar com as dicotomias estruturantes do pensar inauguradas pela metafísica como sujeito-objeto, teoriaprática, sensível-inteligível, corpo-alma, que determinam, a priori, elementos estruturais de nossos horizontes epocais.

Na medida em que, em Ser e tempo, Heidegger toma o homem como ser-aí (Dasein) e que seu existir (ek-sistere) ${ }^{1}$ é fato de sempre já descobrir-se lançado nas concreções fáticas do mundo na realização de possibilidades de ser, sendo, a cada vez, as suas possibilidades de ser. Dessa maneira, a busca de um questionamento sobre o sentido do ser em geral pode nos colocar inelutavelmente face a face com a nossa abertura constitutiva de sentidos, nossa tessitura semântica, ou seja, com nossas verdades, ou ainda, em outras palavras, com o nosso próprio ser. Assim, o Dasein não apenas situa-se no mundo de forma justaposta como um objeto com outro, mas habita-o co-relacionando-se com tudo a partir de uma compreensão de ser. Tal modo de "ser" e "habitar", por conseguinte, "cuida" de uma tessitura histórico-referencial que remonta à estrutura ontológica do Dasein de estar permanentemente referido a outro ente.

Inicialmente, buscaremos fazer uma apresentação sucinta e objetiva da ontologia heideggeriana com base em sua obra mais conhecida: Ser e tempo (Sein und Zeit), publicada em 1927, na qual o autor aborda a questão do ser por caminhos diversos daqueles percorridos até então pela tradição. O objetivo da ontologia de determinar a quididade dos entes transforma-se, então, numa questão fenomenológica e hermenêutica, sob a influência principal, por um lado, de Edmund Husserl e, por outro, de Wilhelm Dilthey. Diante disso, teremos por finalidade situar o leitor em relação à trajetória do pensamento heideggeriano que, ao se tornar inicialmente público nas reflexões expressas em Ser e tempo, lança mão de uma analítica da existência, sendo futuramente cunhado como

\footnotetext{
1 Embora o termo Dasein já fosse corrente na filosofia alemã, Martin Heidegger irá atribuir um sentido muito específico no âmbito da analítica existencial empreendida em Ser e tempo. Assim, Dasein poderia ser traduzido por ser-aí, aí-ser, aí-sendo, sendo-o-aí, pre-sença etc. De fato, a grande amplitude semântica da língua alemã, neste caso muito particular, faz com que haja problemas de tradução em praticamente todos os idiomas a fim de encontrar a melhor versão para expressar o que está em jogo neste conceito central do pensamento heideggeriano. Por isso mesmo, tendo Dasein (ser-aí) um sentido totalmente diferente da concepção filosófica tradicional, Heidegger entende o modo do existir humano como sendo o único ente que, de fato, existe.
} 
fenomenologia hermenêutica. Tal pensamento consiste na descrição interpretativa das estruturas ontológicas fundamentais do existir humano, descrição esta possibilitada pela atitude de suspensão de qualquer forma de objetivação do ser do homem como pessoa, eu, consciência, sujeito, seja em sentido psicológico seja em sentido transcendental (PÖGGELER, 2001, p. 319-389).

\section{Demarcando as origens da fenomenologia hermenêutica}

No breve texto Meu caminho para a fenomenologia (1973), Martin Heidegger sinaliza um momento crucial em sua formação, quando se apercebe quanto à fundamentalidade da questão do ser a partir da leitura da obra de Franz Brentano: Sobre os múltiplos significados do ser segundo Aristóteles (Von der mannigfachen Bedeutung des Seinden nach Aristoteles, de 1862) (STEINER, 2013, p. 57). Importante frisar que tal despertar se deu no ano de 1907, quando ainda cursava a escola de nível secundário no seminário católico de Friburgo. Mais especificamente, ele aponta para a frase que mais lhe chamou a atenção nesta obra, que foi a frase de Aristóteles ao dizer que o ente se manifesta, em conformidade com o seu ser, de diversas maneiras (HEIDEGGER, 2012b, p. 110115; HEIDEGGER, 2006, p. 282-284; MORAES, 2017, p. 45-46). Tal frase de Aristóteles guarda, segundo Heidegger, a questão determinante quanto à escolha do caminho que seu pensamento iria trilhar desde então: qual a determinação fundamental e unitária do ser que rege o ente em suas múltiplas significações? Dois anos mais tarde, em 1909, Heidegger ingressa numa rápida incursão na teologia, começando a cursá-la na Universidade de Friburgo. O flerte com a teologia duraria apenas quatro semestres, quando, então, o ainda jovem Heidegger se voltaria integralmente para a filosofia, para jamais deixá-la. Ao abandonar a teologia, Heidegger distancia-se do pensamento escolástico então predominante. Contudo, a "influência teológica" se faz presente em algumas importantes noções apresentadas em sua obra mais conhecida: Ser e tempo. Noções como - segundo Benedito Nunes - "temor" e "angústia", por exemplo. Kierkegaard, Santo Agostinho e Lutero também se fazem presentes na composição de uma sutil sombra teológica do pensamento do filósofo, muito embora ele não deixe de marcar de forma contundente em diversos textos 
anteriores a Ser e tempo a distância entre a teologia e a filosofia. A mentalidade positivista encontrava na Universidade de Friburgo um importante foco de resistência na Alemanha aos seus preceitos sustentados pelo neokantismo ${ }^{2}$. Nunes (1992) aponta que, naquele período, crescia a crítica à racionalidade científica inerente às ciências naturais. O pensamento de Nietzsche desempenhava um papel preponderante neste movimento, apontando para o primado da experiência vital frente à abstração metafísica. Ganhava força a relação entre poesia e filosofia já iniciada por Hölderlin na primeira metade do século XIX, tendo sido abafada na segunda metade deste mesmo século pela teoria do conhecimento de cunhagem neokantiana (STEINER, 2013, p. 113-166).

De fato, a perspectiva epistemológica do neokantismo imperava no quadro filosófico alemão daquela época. O próprio Heidegger, ao se fixar no curso de filosofia, propaga de certa forma esta perspectiva. Porém, ele rechaça o positivismo do neokantismo mais tradicional, que enfatiza as questões relativas às ciências da natureza. De qualquer forma, não se pode negar que ele encontra em Kant um interlocutor de peso. Para que se ventilem as incursões e dissonâncias entre estes dois expressivos pensadores alemães, não podemos prescindir aqui de um maior clareamento do quadro filosófico dos dois últimos séculos. Diferentemente do século XVII, quando a principal questão que se colocava era a discussão em torno do inatismo, ou seja, se o conhecimento seria inato ou adquirido, sendo Descartes, Leibniz e Locke os principais expoentes desta época, o século XVIII vai propor uma nova abordagem da teoria do conhecimento. Passa a haver uma preocupação em torno de como se processa o conhecimento, bem como onde se encontram os "limites" do conhecer.

Como é sabido, Hume e Kant apresentam duas teorias bastante distintas neste período. Contudo, apresentaremos aqui, de maneira sintética, a forma como o pensador inglês David Hume (1711-1776) apresenta seu ponto de vista sobre as percepções da mente humana. Hume diferencia as percepções da mente em dois gêneros: "impressões" e "ideias". A diferença entre elas seria, segundo ele, o

\footnotetext{
${ }^{2}$ Movimento nascido na Alemanha a partir de 1860, caracteriza-se por assimilar a filosofia à teoria do conhecimento. Neste caso, a teoria do conhecimento é considerada o único campo capaz de impedir a dissolução da filosofia, seja num pensamento especulativo apartado das ciências positivas, seja num materialismo dogmático. Se, por um lado, o neokantismo se une ao naturalismo, por outro, encontra-se com o positivismo, o que é uma consequência natural de sua ontofobia (FERRATER MORA, 1964, p. 269). Um dos nomes mais expressivos do neokantismo foi certamente Ernst Cassirer (1874-1945), com quem Heidegger realizou um debate na cidade de Davos, na Suíça, em 1929 (KIRCHNER, 2019, p. 279-307).
} 
grau de força e a vivacidade com que "atingem" a mente humana. As imagens mais "fortes e violentas" são as impressões, enquanto que as mais "fracas" são as ideias. Ambas, tanto as impressões como asideias, podem ser classificadas em simples ou complexas. Caso possa ser fragmentada em várias partes, é compreendida como complexa; sendo indissolúvel, dir-se-á simples. Há, portanto, uma grande semelhança entre nossas impressões e ideias em todos os pontos, exceto em seus graus de força e vividez, de forma que as ideias parecem ser os reflexos das impressões. É através das percepções de simples e complexas que poderemos limitar a conclusão da semelhança entre as impressões e as ideias. As ideias complexas não necessitam possuir impressões que lhes correspondam inteiramente, ou seja, é possível possuir a ideia de um lugar conhecido com muros de ouro e pedras de rubi, utilizando, assim, duas ideias para formar uma só coisa. Além disso, nossas impressões complexas nunca são copiadas de maneira exata: mesmo que nós tenhamos efetivamente visto uma cidade, somos incapazes de guardar na memória todas as suas ruas e aspectos nitidamente. Não há, portanto, uma regra universalmente verdadeira de que nossas impressões sejam cópias exatas das nossas ideias complexas. Quanto às percepções simples, Hume afirma que "a regra não comporta exceção, e que toda ideia simples tem uma impressão simples que se assemelha a ela; e toda impressão simples tem uma ideia correspondente" (HUME apud PEREIRA, 2004, p. 194). Dada esta tese, Hume crê que é a partir da experiência que se formam as ideias e que o inverso é impossível. Se tomarmos inato por "natural", então, segundo o autor, todas as percepções da mente serão inatas ou naturais. Porém, se admitirmos os termos "inato" e "impressões" tal como definidos por ele, "todas as nossas percepções são inatas e nenhuma de nossas ideias o é" (HUME apud PEREIRA, 2004, p. 195).

Não obstante a diferença de perspectivas entre Hume e Kant, este último não deixa de considerar em seu livro mais lido e mais influente - a Crítica da razão pura (1781) - que sua concepção nasce, também, como um fruto da leitura de Hume e do que o próprio Kant vai denominar como o despertar de seu "sono dogmático"3. Nesta obra, Immanuel Kant (1724-1804) buscou demarcar os limites

\footnotetext{
${ }^{3}$ Logo na abertura - "§ 1. Necessidade de uma retomada explícita da questão do ser" -, referindose a Kant, Heidegger escreve em Ser e tempo: "No âmbito dos conceitos fundamentais da filosofia, e até com relação ao conceito de 'ser', é um procedimento duvidoso recorrer à evidência, uma vez que o 'evidente', isto é, 'os juízos secretos da razão comum' (Kant), deve ser e permanecer o tema explícito da analítica ('o ofício dos filósofos')" (HEIDEGGER, 2006, p. 39-40).
} 
de todo o conhecimento a priori, ou seja, do conhecimento que independe da experiência, por mais que não prescinda dela ${ }^{4}$. A partir de uma postura crítica, ele combate os sistemas metafísicos de caráter dogmático, como o racionalistaintelectualista de Christian Wolff (1679-1754). Tais teses, por se construírem com base em métodos estritamente lógico-dedutivos, eram tidas como irrefutáveis. A alternativa cética diante de tais métodos dogmáticos, representada pelo empirismo de $\mathrm{Hume}^{5}$, por exemplo, também eram combatidos por Kant:

Ora, no tocante ao meu trabalho da Crítica da razão pura, o qual foi, sem dúvida, provocado por essa doutrina céptica humiana, indo no entanto muito mais além, e abrangendo todo o campo da razão pura teórica no uso sintético, por conseguinte, também aquele que se chama metafísica em geral, procedi da maneira seguinte relativamente à dúvida do filósofo escocês quanto ao conceito de causalidade (KANT, 2008, p. 65; cf. também KANT, 2001, p. 612).

Interpõe-se, então, a principal questão de fundo que vai orientar as mais de 800 páginas de sua principal obra crítica, a saber, a pergunta sobre como são possíveis juízos sintéticos a priori. Na referida obra, Kant argumenta se tempo e espaço são formas fundantes de percepção (formas da sensibilidade), que funcionam como "ferramentas da mente", mas que só se dão ao uso na experiência. Não nos seria possível, portanto, imaginar alguma coisa que existe como estando fora do tempo e como não tendo extensão no espaço. Enfim, assim considerado e fundamentado por Kant, a mente humana não poderia produzir tal ideia.

Além das formas da sensibilidade, Kant também vai propor que há o entendimento (Verstand), e que este seria uma faculdade da razão (Vernunft). Ele seria o responsável por nos fornecer as categorias com as quais podemos operar as sínteses do múltiplo e do diverso da experiência. Assim, os juízos sintéticos a priori só são possíveis, porque há uma faculdade da razão - o entendimento -

\footnotetext{
${ }^{4}$ Interessado desde os primórdios de sua vida intelectual pela ciência newtoniana, já constituída plenamente no seu tempo, e preocupado com a confusão conceitual a respeito do debate sobre a natureza do nosso conhecimento, Kant pergunta-se se é possível uma "razão pura" independente da experiência. Daí seu pensamento ser mais conhecido como "criticismo".

${ }^{5}$ Segundo o filósofo inglês, o sujeito do conhecimento é sujeito psicológico, atuando como simples agente de associações de representações sensíveis. Para ele, o "fenômeno" é puro conteúdo de consciência. É pura representação. A causalidade perde nessa perspectiva o caráter de princípio necessário que tem no seio do racionalismo dogmático. Seu fundamento passa a ser a natureza puramente subjetiva e psicológica.
} 
que nos fornece categorias a priori-como causa e efeito - os quais nos permitem emitir juízos sobre o mundo.

No entanto, tais categorias são próprias do conhecimento da experiência, não nos sendo possível empregá-las fora do campo experiencial. Eis, assim, a razão pela qual, segundo a filosofia crítica de Kant, disso parece decorrer que a experiência não é mais puramente receptiva no sentido reconhecido pelo empirismo de Hume. A experiência no sentido atribuído pela filosofia transcendental é apenas receptiva no que se refere à sensibilidade, porém, não no que se refere ao entendimento. Assim, diante do impasse, da tensão que emerge do sujeito estritamente lógico da filosofa dogmática frente ao sujeito psicológico da filosofia cética, Kant reivindica um sujeito transcendental. Trata-se da estrutura apriorística do sujeito que torna possível toda e qualquer experiência. Nela, a sensibilidade e o entendimento são as faculdades fundamentais ${ }^{6}$.

Com efeito, uma apresentação sucinta das bases do pensamento kantiano oferece-nos a possibilidade de compreendermos suas implicações na perspectiva transcendental no pensamento de Friedrich Schleiermacher, Wilhelm Dilthey, Edmund Husserl, e, consequentemente, de Martin Heidegger (STEINER, 2013, p. 113-114). Adiantamos, porém, que, a partir de Kant, Heidegger faz um recuo crítico para uma dimensão mais originária do que a dimensão da representação, na qual se desenrola a relação sujeito-objeto ${ }^{7}$.

Heidegger mesmo reconhece posteriormente que, ao final dos anos de 1920, Kant tornara-se seu "patrono", isto é, o filósofo de Königsberg fora um dos principais interlocutores durante os anos que concebeu e desenvolveu o tratado

\footnotetext{
${ }^{6}$ A expressão "transcendental" em Kant significa aquilo que é anterior a toda a experiência: "Chamo transcendentala todo conhecimento que em geral se ocupa menos dos objetos, que do nosso modo de os conhecer, na medida em que este deve ser possível a priori" (KANT, 2001, p. 53). Contudo, mesmo fazendo uma crítica do racionalismo e do empirismo, Kant segue um processo que redunda num idealismo, daí o seu pensamento ser conhecido como "idealismo transcendental", pois, ainda que reconheça a experiência como fornecedora da matéria do conhecimento, é o nosso espírito, através de suas estruturas a priori, que constrói o objeto do seu saber. De fato, no contexto de Ser e tempo, este conceito possui um outro sentido: "O ser é $O$ transcendens pura e simplesmente. A transcendência do ser do ser-aí é privilegiado porque nele reside a possibilidade e a necessidade da individuação mais radical. Toda e qualquer abertura de ser enquanto transcendens é conhecimento transcendental. A verdade fenemenológica (abertuda de ser) é veritas transcendentalis (HEIDEGGER, 2006, p. 78).

7 Uma das críticas heideggerianas mais contundentes da perspectiva metafísica da cisão homemmundo e das naturais dicotomias dela decorrentes - dentre as quais as de sujeito-objeto encontrmos em Ser e tempo. Tendo como referência o conceito de "mundo" em sentido ôntico e ontológico, Heidegger irá desenvolver a totalidade estrutural "ser-no-mundo" ao longo dos capítulos 2, 3, 4 e 5, onde procura preservar analiticamente a unidade ontológica da existência do Dasein (HEIDEGGER, 2006).
} 
Ser e tempo. Ele reconhece isso num dos prefácios do livro Kant e o problema da metafísica, publicado em 1929, do qual traduzimos a passagem a seguir:

\begin{abstract}
Durante a elaboração da preleção ministrada no Semestre de Inverno de 1927/28 sobre a Crítica da Razão Pura de Kant, atentei para o capítulo sobre o esquematismo e vi aí uma conexão entre o problema das categorias, isto é, o problema do ser oriundo da metafísica tradicional, e o fenômeno do tempo. Assim, entrou em jogo o questionamento de Ser e tempo como abordagem prévia para a interpretação de Kant que procurei empreender. $O$ texto kantiano tornou-se um abrigo para procurar em Kant um defensor da questão do ser levantada por mim (KANT, 2019, p. 10).
\end{abstract}

Entretanto, a principal obra de Heidegger e que o anunciaria e consolidaria no meio filosófico no século $X X$ começa a nascer a partir do distanciamento da seara neokantiana. A fenomenologia do mestre Edmund Husserl e a hermenêutica de Wilhelm Dilthey se entroncam, fornecendo as bases filosóficas e epistemológicas da "fenomenologia hermenêutica" heideggeriana.

\title{
2. Schleiermacher e Dilthey: principais influências da tradição hermenêutica
}

Hans-Georg Gadamer (1900-2002), tendo sido um dos alunos de Heidegger mais expressivos, é certamente uma referência muito importante para nossos objetivos neste artigo. De fato, em Verdade e método: Traços fundamentais de uma hermenêutica filosófica (Wahrheit und Methode: Grundzüge einer philosophischen Hermeneutik) (publicado em 1960), apresenta-nos o objetivo principal do pensamento de Wilhelm Dilthey (1833-1911), que seria complementar à crítica da razão pura mediante uma crítica da razão histórica, ou seja, "descobrir as categorias do mundo histórico, que seriam capazes de sustentar as ciências humanas" (GADAMER, 2007; NASCIMENTO, 2019, p. 29-34). A diferença fundamental desta perspectiva de historicidade já assumida pelos neokantianos é que estes propunham uma transposição da problemática epistemológica das ciências naturais para as ciências humanas ou históricas (DILTHEY, 2010, p. 13-143). Dilthey, ao contrário, não via a estrutura da experiência histórica enquanto constituída à base de fatos aos quais se 
acrescentariam relações de valor, mas, sim, que tal estrutura está baseada na historicidade inerente à própria experiência ${ }^{8}$.

Para melhor clarificarmos a influência da perspectiva hermenêutica diltheyana no pensamento de Heidegger, precisamos compreender melhor a estruturação histórica deste campo de saber, que tem no pensador alemão Friedrich Schleiermacher (1769-1834) - teórico que produziu suas principais reflexões no início do século XIX -, como fundador da hermenêutica contemporânea. Embora Schleiermacher não tenha sido o primeiro a ocupar-se da teoria da interpretação, uma vez que os debates acerca de tal fenômeno remontam aos gregos e atravessam toda a cultura ocidental, foi somente a partir de suas reflexões que a hermenêutica ganhou estatuto de autonomia e, enquanto disciplina, adquiriu seus atuais delineamentos. Schleiermacher considerava que a hermenêutica, até o século XVIII, se restringia a uma técnica auxiliar da filologia e da teologia, compondo-se tão somente por "coleções de regras particulares reunidas por meio das observações dos mestres, algumas vezes claramente definidas, outras beirando a indefinição, arranjadas ora confusamente ora comodamente" (SCHLEIERMACHER, 2004, p. 16). Tais coleções fragmentárias de regras não estruturavam, ainda, uma metodologia propriamente dita, pois não eram capazes de expor, "sob uma forma adequada e científica, toda a extensão e as razões de ser do processo de compreensão" (SCHLEIERMACHER, 2004, p. 26).

Com vistas ao ultrapassamento desta "precária" condição epistemológica, Schleiermacher incumbe-se de suplantar esses conjuntos de orientações parciais, fornecendo uma descrição mais estruturada, sistemática e completa do processo interpretativo, que se propõe a oferecer tanto uma descrição correta do modo como a compreensão ocorre quanto uma orientação supostamente mais condizente dos "intérpretes" no processo interpretativo. Ele lamentava também que, em face da fragmentação da hermenêutica em uma série de disciplinas particulares, "a hermenêutica como arte da compreensão não existisse como uma área geral, apenas existe uma pluralidade de hermenêuticas especializadas" (SCHLEIERMACHER apud PALMER, 1986, p. 91).

\footnotetext{
${ }^{8}$ Hoje é sabido que, desde a aula de habilitação ("O conceito de tempo na ciência histórica", de 1915) até as conferências de Kassel ("O trabalho de investigação de Wilhelm Dilthey e a atual luta por uma concepção histórica do mundo", de 1925), Heidegger sempre esteve ocupado com as ideias diltheyanas (HEIDEGGER, 2009; KIRCHNER, 2012).
} 
Neste período, portanto, no início do século XIX, havia somente uma gama de disciplinas hermenêuticas que serviam como técnicas de interpretação aplicáveis aos seus diversos campos determinados, fundamentalmente a filologia, a teologia e o direito. Sendo conjuntamente teólogo, filólogo e filósofo, Schleiermacher repudiava essa fragmentação, entendendo que não fazia sentido desenvolver uma teoria para a interpretação da Bíblia, outra para a interpretação dos clássicos, outra para a interpretação da literatura moderna, outra para a interpretação da literatura oriental e assim por diante. Embora cada um desses campos pudesse ter as suas peculiaridades e especificidades, decorria que se estava diante de várias aplicações do mesmo processo de compreensão, o que despertou nele a idealização de um projeto de uma hermenêutica geral, que comportasse a interpretação de todos os textos, fossem eles escritos ou orais, antigos ou modernos, sacros ou profanos. Descortinou-se, assim, a possibilidade de transição da hermenêutica, de uma técnica auxiliar dos diversos campos do saber para uma descrição unificada dos processos de compreensão. Gadamer pontua que Schleiermacher se opôs à hermenêutica tradicional de sua época, porque passou a concentrar-se na compreensão do texto enquanto portador de significado e não no estudo dogmático do texto como um veículo que poderia conduzir à verdade. Refutando tal perspectiva linear e dogmática, Schleiermacher propunha a autonomia do sentido do texto, uma vez que o seu objetivo já não era revelar a eventual verdade oculta no texto, mas compreender o próprio sentido do texto, independentemente da veracidade ou não desse significado. Com isso, ele unificou o estudo de textos sagrados e profanos, clássicos e modernos, submetendo suas compreensões à mesma metodologia. Como atesta Gadamer, "a compreensão e interpretação tanto da Bíblia como da antiguidade clássica foram liberados do interesse dogmático" (GADAMER' 2007, p. 269-270).

Identifica-se também em Schleiermacher, diferentemente de seus antecessores, que procuraram entender os processos hermenêuticos, a tentativa de elaborar uma teoria hermenêutica tão próxima quanto possível dos padrões de cientificidade. Além disso, sendo ele fundamentalmente um teólogo, visualiza-se em sua busca o objetivo de conformar uma teologia científica, por meio da elaboração de uma metodologia adequada de interpretação dos textos bíblicos (GADAMER 2004, p. 111-142). No entendimento de Gadamer, o qual, no século $\mathrm{XX}$, retomou as ideias de Schleiermacher sobre este tema: 
Quem quiser compreender um texto, realiza sempre um projetar. Tão logo apareça um primeiro sentido no texto, o intérprete projeta um sentido para o texto como um todo. $O$ sentido inicial só se manifesta, porque ele está lendo o texto com certas expectativas em relação ao seu sentido. A compreensão do que está posto no texto consiste precisamente no desenvolvimento dessa projeção, a qual tem que ir sendo constantemente revisada, com base nos sentidos que emergem, à medida que se vai penetrando no significado do texto (GADAMER, 2007, p. 356) ${ }^{9}$.

Tal revisão, contudo, é um processo circular infindável, na medida em que não é possível conhecer todos os elementos comparativos que podem estimular novas projeções divinatórias. Para uma melhor elucidação deste processo, recorramos a um exemplo do nosso cotidiano. Quantas vezes entendemos o significado de uma cena que acontece no início do filme apenas quando chegamos ao final da história? Quantas vezes saímos do cinema relembrando os episódios iniciais e revendo o modo como eles deveriam ser interpretados? Isso acontece, porque cada cena particular somente pode ser entendida dentro do contexto da obra completa. Porém, a obra completa é formada pela sequência dos episódios particulares.

Para que migrasse do pensamento tópico (catálogo de cânones dotados de autoridade) e ingressasse no pensamento metódico (convertendo-se em um sistema abstrato de regras), foi preciso que a própria metodologia da hermenêutica se tornasse objeto de reflexões específicas. $O$ maior desenvolvimento desta discussão metodológica só veio a dar-se no século XIX, quando os teóricos da interpretação se voltaram sobre sua própria atividade e se perguntaram seriamente acerca do significado dos métodos que eles próprios definiam. O aprofundamento dessa reflexão levou a hermenêutica a voltar-se sobre si mesma e a promover um questionamento sobre a própria metodologia do processo interpretativo, dando então um passo significativo na direção da transformação da racionalidade moderna, a saber, da auto-reflexividade. Tal passo normalmente é atribuído a Schleiermacher, sendo o primeiro teórico a tematizar a própria interpretação e a buscar esclarecer os modos como interpretamos não somente textos em concreto, bem como toda e qualquer ação de que possamos

\footnotetext{
${ }^{9}$ Considerando que tradução brasileira de Verdade e método das passagens citadas neste artigo apresentam, às vezes, algumas divergências em relação à tradução inglesa, fizemos um cotejo entre as duas versões (cf. GADAMER, 2006 e 2007).
} 
vir a ter uma participação. Com isso, a hermenêutica deixou de ser uma disciplina auxiliar da teologia, do direito ou da filologia, e passou a se mostrar como um campo autônomo de pensamento.

A envergadura e as consequências deste passo conduziram Schleiermacher a amplificar sua visão tanto sobre as potencialidades quanto sobre os limites de uma metodologia da interpretação. Fundamentalmente, ele alertou que qualquer metodologia interpretativa não poderia ser reduzida, tal como nas ciências naturais, a um sistema de regras que pudessem ser definidas a priori e aplicadas em qualquer situação e contexto. Com isso, apesar de suas pretensões metodológicas, Schleiermacher não alimentou ilusões sobre a possibilidade de reduzir a hermenêutica a um conjunto definido de regras de interpretação, especialmente no tocante ao elemento divinatório. Ele chegou mesmo a afirmar que "regras gerais, para a determinação correta da significabilidade, deixam-se fornecer parcamente. Os contextos indicam o acento e o tom do conjunto" (SCHLEIERMACHER, 2004, p. 85). Nesse aspecto, ele demonstrou uma consciência metodológica atípica e originária para o cientificismo de sua época, pois, "quase como nenhum outro, ele possuía um senso agudo em relação ao limite do metodologizável e sobre a necessidade de uma adivinhação empática no reino da interpretação" (GRONDIN, 1999, p. 130).

Nesta mesma direção se desenvolveram os esforços de Wilhelm Dilthey que, no final do século XIX, propôs a diferença entre as ciências da natureza (que são voltadas à explicação causal e matematizante) e as Geisteswissenschaften, ou seja, as ciências do espírito (que são voltadas à compreensão do homem). De acordo com RichardPalmer, Dilthey sustentava que compreensão "era a palavra-chave para os estudos humanísticos", pois, enquanto as ciências exatas explicam a natureza, "os estudos humanísticos compreendem as manifestações da vida" (PALMER, 1986, p. 112). E vai além: segundo Dilthey, "explicamos a natureza, mas há que se compreender o homem" (PALMER, 1986, p. 120), pois "a dinâmica da vida interior de um homem era um conjunto complexo de cognição, sentimento e vontade, e esses elementos não são sujeitáveis às normas da causalidade e à rigidez de um pensamento mecanicista e quantitativo" (PALMER, 1986, p. 109). Em outras palavras, a aplicação da metodologia positivista às ciências do homem não nos conduziria à construção de um saber adequado, na medida em que a 
compreensão dos fenômenos humanos requer uma outra abordagem do ponto de vista metodológico e hermenêutico (DILTHEY, 2010).

Quanto à natureza desta experiência, Dilthey acreditava que as "ciências do espírito" ampliam o pensamento já implícito na experiência da vida. A experiência da vida - tal como apontado por Benedito Nunes (1992) - engloba sujeito e objeto e os fenômenos da realidade histórica são trans-individuais, embora tenham origem na estrutura psíquica do indivíduo, possuindo, assim, um caráter propriamente compreensivo. Portanto, os fenômenos históricos seriam inseparáveis das vivências e não poderiam ser reduzidos a conexões causais. $O$ mundo histórico produz espontaneamente estruturas significativas que condicionam as ciências do espírito. Paul Ricoeur (1913-2005), por exemplo, assinala que Dilthey explicita, pela primeira vez, a dualidade entre compreensão, própria das ciências do espírito, e explicação, própria das ciências naturais (RICOEUR, 1977). Marca-se, portanto, a diferença entre o caráter psicológico da compreensão e o caráter da essência inapreensível da coisa natural. Com isso, Dilthey sustenta que a vida apresenta em si mesma uma estrutura hermenêutica e é acusado de cair num relativismo epistemológico, apesar de suas pretensões objetivas.

Contudo, as ciências do espírito tampouco poderiam ser confundidas com a filosofia idealista do iluminismo, uma vez que esta perspectiva filosófica era metafísica e não uma ciência. Com isso, a proposta de Dilthey era livrar as ciências do espírito tanto de sua vinculação metafísica (sem o que elas não se constituiriam como ciência), quanto de uma redução positivista (sem o que elas não poderiam compreender seu objeto) (DILTHEY, 2010, p. 138-143). Indiscutivelmente, não se pode negar ou refutar o gigantismo deste desafio que, em sua primeira parte, tem a ver com a superação dos pressupostos idealistas do hegelianismo que dominava as teorias da história daquela época.

Georg Wilhelm Friedrich Hegel (1770-1831) desempenhou um papel importantíssimo na valorização filosófica da historicidade, sendo o primeiro grande filósofo moderno a pensar o homem como um ser histórico, rompendo, com isso, um padrão que se estendia desde o pensamento grego, que insistia em uma ontologia baseada no esclarecimento das essências imutáveis e universais do homem e da natureza. Mesmo Kant, que foi certamente o filósofo mais importante da geração anterior à de Hegel, não pensava ainda o mundo de maneira histórica, 
na medida em que ancorava suas ideias nos pontos fixos da subjetividade, que são juízos apriorísticos cuja validade é racional e necessária. Desta forma, ele mesmo acabou ratificando as posições clássicas e medievais, que buscam a explicação correta no esclarecimento de uma certa ordem natural das coisas, apesar de, com Kant, a lógica cósmica ser substituída por uma lógica cognitiva, individual e presente em cada um dos homens.

Contudo, a introdução da historicidade por parte da filosofia hegeliana foi, inquestionavelmente, uma inovação relevante, mas que conduziu a um discurso histórico predominantemente filosófico e não científico. Em vez de uma ciência que se limitasse a descrever o seu objeto, o processo histórico era visto a partir de modelos metafísicos de compreensão, o que resultava em uma narração da história que partia de padrões não-históricos. Como afirma Gadamer: "Há muitas formas de pensar a história a partir de um padrão situado fora dela própria" (GADAMER 2007, p. 274). Wilhelm von Humboldt (1767-1835), por exemplo, pensava a história como um processo de decadência da perfeição dos modos gregos de vida; a teologia histórica gnóstica pensava o futuro como a restauração da perfeição dos tempos originais; Hegel pensava a história como a realização do espírito absoluto (GADAMER 2007, p. 274-278). Em todos esses discursos, a história é pensada de uma forma a-histórica, pois o discurso histórico é organizado nas bases de uma filosofia idealista que não se coaduna com um estudo científico das fontes.

Buscando contrapor esse discurso filosófico da história com o intento de construir um discurso propriamente científico, Dilthey transformou o problema ontológico e metafísico (qual o sentido da história?) em um problema epistemológico, ou seja, relativo ao método científico (como compreender o homem em sua historicidade?). No entanto, essa nova perspectiva cientificista não negava um sentido ao processo histórico, mas afirmava que "a história tem um sentido em si mesma" (GADAMER' 2007, p. 276-277). Assim, em vez de estipular um sentido metafísico necessário para a história, pensadores como Leopold von Ranke (1795-1886) e Johann Gustav Droysen (1808-1884) opuseram-se ao hegelianismo então dominante e tentaram viabilizar uma teleologia que não fosse transcendente (ou seja, não estivesse fora dos processos históricos), mas que fosse imanente (ou seja, que pudesse ser percebida a partir de uma investigação da própria história). 
Segundo Gadamer, esses teóricos apresentam a história como "uma 'soma em curso', com o fim de renunciar a qualquer pretensão de se construir aprioristicamente a história do mundo, e com isso acham que estão absolutamente no terreno da experiência" (GADAMER 2007, p. 282). Tal transposição do campo da transcendência para o campo da imanência é típica de uma perspectiva de cientificização, pois a identificação do sentido imanente deve ser derivada da própria observação dos fatos. Assim, a imanentização do sentido reforça a possibilidade de tratar a história como um objeto dotado de sentido, mas sem recair no anti-historicismo implicado pela definição metafísica de um sentido necessário e apriorístico para o processo histórico. Tornava-se necessário, assim, aprofundar a afirmação de Dilthey de que "chegamos ao conhecimento de nós próprios não através da introspecção, mas sim através da história" (PALMER, 1986, p. 107). Ficava, então, estabelecido o desafio de um historicismo que se pretendesse científico: definir um sentido histórico (e não a-histórico) para a própria história. Mas que tipo de abordagem seria capaz de identificar, no interior da própria história, um sentido imanente? Certamente, não poderia ser a das ciências empíricas, com um discurso externo e explicativo que não se coaduna com o objeto histórico, na medida em que "a própria história não é, portanto, somente um objeto do saber, mas está ontologicamente determinada pelo saber sobre si mesma. 'O saber sobre ela é ela própria'” (GADAMER' 2007, p. 285). Essa circularidade auto-referente inviabiliza a utilização do discurso explicativo das ciências, com sua produção de discursos externos que adotam a forma de sistemas sincrônicos. A visualização dessa incompatibilidade poderia ter conduzido à negação da cientificidade do histórico, conduzindo-o a sedimentar-se como um saber alternativo à própria ciência. Porém, essa saída não era admissível no ambiente do final do século XIX, quando imperava um cientificismo que negava qualquer autoridade a um conhecimento que não se qualificasse como científico.

Tal processo iniciou-se com Ranke e Droysen, que propuseram ler a história como um texto, localizando o seu sentido como quem identifica o seu sentido interno, como o de uma produção literária. Eles se inspiraram nas concepções metodologizantes da hermenêutica e formularam a tese de que era adequado ler a história como quem lê um texto. Assim, o que caberia à história não seria uma simples descrição dos fatos, mas uma compreensão do processo histórico. No entanto, tal perspectiva não era ainda um método, e foi justamente um aluno de 
Ranke que tomou para si esta tarefa, inspirando-se na obra de Schleiermacher, para conduzir a hermenêutica de uma metodologia de identificação dos sentidos imanentes dos textos, isto é, a uma metodologia de identificação dos sentidos imanentes dos processos históricos (NASCIMENTO, 2019, p. 34-49).

Este aluno foi justamente Wilhelm Dilthey, que imprimiu rigor nesta tentativa de fixar a hermenêutica como uma metodologia para as ciências do espírito. Foi com Dilthey que se consolidou a "transferência da hermenêutica para a historiografia", firmando-se a ideia de que "não somente as fontes históricas chegam até nós como textos, mas também a realidade histórica é em si um texto que deve ser compreendido" (GADAMER, 2007, p. 270-295). A hermenêutica de Dilthey, portanto, constitui-se como um método para a fixação objetiva do sentido imanente da história, o que implica uma oposição ao sentido transcendente estabelecido pelo idealismo presente na dialética hegeliana propriamente dita; embora, em ambos os casos, possa se identificar a presença de um pensamento metodológico inspirado pelo cientificismo do século XIX. O discurso das ciências modernas constitui-se no próprio discurso do método, pois a metodologia nos fornece justamente o padrão de verdade utilizado pela ciência. Portanto, a questão de Dilthey tinha um forte viés epistemológico: que método seria capaz de conduzir a uma verdadeira compreensão? Que tipo de aproximação esclareceria o sentido imanente à própria história e, com isso, que poderia servir como base para uma compreensão histórica do próprio homem?

Tal preocupação metodológica conduziu Dilthey ao enfrentamento das aporias de um historicismo metodológico, que terminava sempre dividido entre duas perspectivas: "a meio caminho entre a filosofia e a experiência" (GADAMER, 2007, p. 270-275). Hegel introduziu o historicismo, mas sob a égide de um idealismo que garantia um sentido transcendente para a história. Dilthey pretendia uma superação dessa metafísica fixista, tomando imenso cuidado, porém, para não recair no relativismo absoluto que não enxerga na história um sentido. Fazia-se, portanto, necessário estabelecer uma forma de identificar de maneira objetiva o sentido imanente da história. Essa imanentização do sentido da história termina por preservá-lo propriamente histórico, na medida em que ele se altera com o curso do processo. Assim, existe uma radicalização do historicismo hegeliano, que pressupunha a existência de um espírito absoluto que funcionava como orientação da própria história, abandonando a ideia de sentidos absolutos e imutáveis para a 
história, mas buscando a possibilidade de um conhecimento objetivo do sentido definido dentro do próprio processo histórico. Porém, na falta deste absoluto metafísico, fazia-se necessário o surgimento de alguma "outra espécie de absoluto", que servisse como ponto de referência para a afirmação de alguma verdade objetiva. Entretanto, como negar o idealismo hegeliano e, ao mesmo tempo, afirmar a presença do sentido objetivo da história?

Com Dilthey, a historicização do homem é acompanhada pela afirmação de que as ações humanas devem ser percebidas como dotadas de uma significação, que pode ser identificada objetivamente por meio de um método. Para ele, esse método é a hermenêutica, cuja validade objetiva se baseia em uma espécie de correspondência ontológica necessária, e não contingente, com tudo o que ocorre na história. Dilthey aponta que "a primeira condição de possibilidade da ciência da história consiste em que eu mesmo sou um ser histórico, e que aquele que investiga a história é o mesmo que a faz" (GADAMER, 2007, p. 300), de tal forma que a consciência histórica é uma forma de autoconhecimento. Desta forma, a nossa própria historicidade permite uma compreensão objetiva da história, inspirada na ideia de Schleiermacher de uma congenialidade na relação entre intérprete e autor, sem a qual não se pode efetuar o salto de uma opinião subjetiva para uma verdade histórica objetiva. Disso decorre, como afirma Gadamer, um nexo imediato entre vida e saber, de tal forma que a experiência histórica vivida possibilita um saber histórico que não precisa de uma justificação discursiva (GADAMER, 2007, p. 318).

Assim, é possível visualizar, por um lado, um retorno aos critérios cartesianos de certeza, em que a verdade é dada por meio de uma evidência racional; e, por outro lado, o remonte a um padrão kantiano, que busca na certeza imediata do sujeito em relação a si mesmo um fundamento adequado para a investigação das formas da sensibilidade e das categorias do conhecimento. Portanto, em nome de uma metodologização do conhecimento histórico, voltamos com Dilthey a uma ontologização idealista das relações entre sujeito e objeto, que é muito bem identificada e exposta por Gadamer na passagem de Verdade $e$ método em que ele fala do "enredamento de Dilthey nas aporias do historicismo" (GADAMER, 2007, p. 295-325). Tais aporias derivam justamente de ele não aceitar radicalmente as consequências da historicidade do conhecimento. Ele afirmou contra Hegel a necessidade de termos consciência da nossa finitude, mas 
buscou construir uma verdade objetiva baseada na contingência, pois não conseguiu desvencilhar-se totalmente da pretensão idealista de uma verdade incondicionada, embora propusesse o ideal inalcançável de um discurso interno à historicidade, mas cuja veracidade não fosse historicamente condicionada.

Notamos assim que, embora se busque com Dilthey a radicalização de uma historicidade, tal proposta é limitada pela permanência do idealismo transcendental, ainda que convertido em uma espécie de imanência. $O$ fato de $O$ homem ter uma percepção imediata da sua historicidade que permite a Dilthey afirmar a objetividade do conhecimento histórico, com tal objetividade do conhecimento acerca da história sendo garantida pela permanência de certas estruturas ontológicas cujo caráter não é histórico e contingente, mas essencial e necessário. Portanto, essa concepção recicla de maneira velada o idealismo que elas próprias afirmam e pretendem combater. Por fim, as metodologias propostas, que deveriam dar margem à identificação de um conhecimento histórico objetivo, não se prestam a uma aplicação objetiva.

Como é sabido hoje em dia, de Dilthey, Heidegger dá uma atenção toda particular à questão da historicidade da compreensão (DILTHEY, 2010). Porém, percebemos que ele retrocede à questão hermenêutica do nível psicológico para uma dimensão mais originária do questionamento ontológica (HEIDEGGER, 2012a; HEIDEGGER, 2009). A questão do sentido, antes de se dar na esfera volitiva de um sujeito pensante, no uso de seus atributos cognitivos e regidos pela lógica imperativa da razão, dá-se, mais originariamente, de forma co-originária e coconstitutiva deste ente cujo modo de ser é a própria abertura descerradora de sentido de mundo. Ou seja, este ente que nós mesmos somos e o mundo com o qual lidamos constituem mutuamente um ao outro, não nos sendo possível pensar um previamente ao outro para constituí-lo enquanto produto, matéria ou sentido. Trata-se, portanto, de um questionamento que se volta para uma dimensão préontológica, ou seja, para uma dimensão do modo de ser deste ente que nós mesmos somos e que aponta para o fato de que a dualidade compreensãoexplicação se apresenta como algo derivado, sendo uma pré-compreensão do sentido do ser.

Portanto, lançando mão de Dilthey, mas ao mesmo tempo ultrapassando-o, Heidegger pretende explicitar a historicidade do sentido em sua dimensão mais originária. Para isso, porém, seria necessário investigar ontologicamente a relação 
entre historicidade e temporalidade, ou seja, evocar de forma explícita as concepções mais basilares de cada um destes conceitos, fato este não realizado nem pela metafísica nem pelas ciências, as quais assumem sem maiores indagações uma concepção "natural" do tempo como "uma pura sequência de agoras, sem começo e sem fim" (KIRCHNER, 2007, p. 67 e 162).

Como já citado, interessado, como Dilthey, pela temática da história e da historicidade da vida, Heidegger desenvolve sua obra capital - Ser e tempo onde a compreensão hermenêutica aparece ligada à exigência urgente de uma reposição da questão do sentido do ser. Heidegger sabe que a questão da historicidade é hermenêutica, porque abriga em si uma outra questão de fundo: o mistério da temporalidade. E este não é um problema gnosiológico qualquer, mas algo que diz essencialmente respeito ao modo de ser do ser-aí que é o ente humano enquanto tal. Esta é uma questão fundamental esquecida pela tradição e que implicaria, antes de mais nada, uma nova maneira de fundamentação (HEIDEGGER, 1985).

De fato, foi Heidegger quem disse com todas as letras: há uma relação circular entre o olho e a imagem e, neste sentido, foi Gadamer quem nos colocou de frente às ideias de que "o que reconhecemos historicamente, no fundo, somos nós mesmos" e que "o conhecimento próprio das ciências do espírito tem em si sempre um quê de autoconhecimento" (GADAMER, 2005, p. 49-56). Heidegger realizou tal empreitada no contexto de uma revisão da ontologia moderna, revisão essa na qual envidou esforços na busca de levar a sério a pergunta pelo sentido do ser. Ele deixou claro que havia uma certa inconsistência nas perguntas sobre o ser do homem, especialmente, na busca da definição da natureza humana.

Heidegger, porém, deixa claro que os sentidos não estão no mundo, mas são frutos da própria atividade humana, que tende a compreender o mundo mediante a atribuição de um sentido ao ser. O homem, portanto, não apenas afirma a existência das coisas, mas confere sentido à sua própria existência, atribuindo-lhe uma significação. Com isso, a hermenêutica assume uma tarefa diferente da que ela tinha até Dilthey, pois já não se trata mais de uma metodologia para compreender um texto ou um autor. Na medida em que a interpretação é vista como uma forma de atribuir sentidos, a hermenêutica torna-se o estudo dos modos humanos de compreensão, mediante a elaboração de sentidos para um mundo que, "em si", é dotado de existência e não de significação. 
Assim, Heidegger deixa de tratar a hermenêutica com uma espécie de teoria da interpretação de textos e passa a afirmar que a compreensão é parte da própria condição humana, sendo determinante no nosso modo de atribuir significados à realidade. Portanto, nenhum desses significados é natural, imutável ou perene: todos eles são frutos da própria atividade hermenêutica, que, como tal, têm um caráter circular, dinâmico, esta, sim, já apontada por Schleiermacher e Dilthey, e ratificada por Heidegger. Porém, afirmando, mas ao mesmo tempo aprofundando esta questão da circularidade, Heidegger dá um passo relevante na renovação da antiga ideia de que, no horizonte ou contexto de um texto, somente é possível compreender o singular a partir do sentido do todo e o todo a partir dos sentidos dos elementos que o compõem. Tal relação circular está presente toda vez que tentamos compreender um texto a partir dele mesmo, o que é um princípio fundamental da atividade interpretativa. Esta circularidade, porém, era vista como viciosa, pois esses movimentos concêntricos nunca levam a uma verdade, uma vez que esta precisa ser baseada em um ponto fixo que lhe assegure objetividade. Então, todo conhecimento ligado a essa estrutura circular não poderia pretender o estatuto de ciência, porque o saber científico constitui-se como um discurso linear e sistemático.

Com efeito, foi justamente Heidegger quem rompeu com esta ideia. Por isso, segundo reconhece Gadamer, o ponto culminante da reflexão hermenêutica de Heidegger não foi a identificação da existência de uma circularidade, mas a afirmação de que esse círculo possui um sentido ontológico positivo: não se trata de um círculo vicioso que impede a compreensão objetiva, mas "uma curiosa 'retrospecção ou prospecção' do questionado (o ser) sobre o próprio questionar, enquanto modo de ser de um ente determinado" (HEIDEGGER, 2006, p. 43-44).

Assim, não pode ser caracterizado como vício o fato de que o ser que reflete sobre si mesmo anda sempre em círculos, pois o resultado da reflexão altera o olhar e constitui o próprio ser que se investiga. Portanto, não é possível a autocompreensão senão dentro desse processo circular, dado que fora dele não existe a compreensão do próprio ser e que, portanto, o processo hermenêutico dá-se como um círculo virtuoso que possibilita a existência da própria compreensão (GADAMER, 2004, p. 72-81). 


\section{A fenomenologia de Husserl como fonte de inspiração e superação}

De Husserl, seu primeiro grande mestre, Heidegger não sofre influências menos decisivas. Ele próprio admite que os dois volumes das Investigações lógicas, de Husserl, sempre estiveram em sua mesa de estudo em Friburgo desde o primeiro semestre, ainda durante o curso de teologia. Esta primeira aproximação do autor das Investigações lógicas deu-se a partir do conhecimento da influência de Franz Brentano (1838-1917). Como expusemos anteriormente, o trabalho de Brentano sobre Aristóteles já desempenhava, desde 1907, um importante papel nas primeiras tentativas de incursão na filosofia por parte de Heidegger. Em Meu caminho para a fenomenologia, ele afirma que buscava "um estímulo decisivo com relação às questões suscitadas pela dissertação de Brentano" (HEIDEGGER, 1973, p. 495; NASCIMENTO, 2019, p. 49-58).

Pelas Investigações lógicas, porém, Heidegger buscava primariamente dissipar uma aparente ambiguidade que se lhe apresentava nesta obra, além de clarificar os procedimentos característicos do pensamento nomeado "fenomenológico". Ele identificava uma contradição do primeiro volume (de 1900) que refutava veementemente o psicologismo em contraposição ao segundo volume (de 1901) que trazia uma descrição dos atos conscientes essenciais para a construção do conhecimento, recolocando a psicologia num lugar de destaque nesta construção:

Husserl recai, com sua descrição fenomenológica dos atos conscientes, na posição do psicologismo que precisamente procurara antes refutar. Se, no entanto, erro tão grosseiro não pode ser atribuído à obra de Husserl, que é então a descrição fenomenológica de atos conscientes? Em que consiste o elemento individualizador da Fenomenologia, já que esta não é nem Lógica nem Psicologia? Manifesta-se aqui uma disciplina filosófica inteiramente nova e que possui dignidade e nível próprios? (HEIDEGGER, 1973, p. 496).

Somente em 1913, com o início da publicação do Anuário de filosofia e pesquisa fenomenológica (Jahrbuch für Philosophie und phänomenologische Forschung), editado por Edmund Husserl, Martin Heidegger encontra a resposta que procurava. Já no seu primeiro volume, Husserl apresenta um tratado que traz no título o elemento caracterizador e o alcance da fenomenologia: Ideias a 
propósito de uma fenomenologia pura e de uma filosofia fenomenológica (HUSSERL, 1962). A partir desta publicação, Heidegger percebe que "fenomenologia pura" é o mesmo que "fenomenologia transcendental", e que a transcendentalidade é a do sujeito do conhecimento, da ação e da valoração. Heidegger acrescenta ainda:

Ambos os títulos, "subjetividade" e "transcendental", indicam que a "fenomenologia" se encaminhava, consciente e decididamente, na esteira da tradição da filosofia moderna; fazia-o, não há dúvida, de tal maneira, que a "subjetividade transcendental" atinge, através da fenomenologia, uma possibilidade de determinação mais originária e universal (HEIDEGGER, 1973, p. 496).

Frente a tais colocações de Heidegger, urge a discussão de alguns pontos do pensamento husserliano no intuito de possibilitar uma melhor compreensão das diferenças inerentes às propostas fenomenológicas de Husserl e Heidegger. Jean-François Lyotard (1924-1998) afirma que há na fenomenologia de Husserl uma "pretensão a-histórica" (LYOTARD, 1967, p. 8). Husserl pretende fundamentar as ciências em bases sólidas numa época de crescimento das perspectivas relativistas. Com sua fenomenologia, ele voltava-se diretamente contra o psicologismo. Essa tendência se caracteriza por identificar o sujeito do conhecimento com o sujeito psicológico e por compreender a verdade como algo do âmbito da evidência subjetiva correspondente à realidade experienciada, certeza que se liga necessariamente a um certo estado de consciência.

Tais teses do psicologismo, inaceitáveis para Husserl, orientam-se para o ceticismo, que já fora alvo da crítica kantiana no século XVII, ceticismo este que encontra sua base no empirismo, sendo a experiência fornecedora apenas do contingente: "Ora, a experiência, fornecendo apenas o contingente e o singular, não pode fornecer à ciência o princípio universal e necessário de uma afirmação semelhante. O empirismo não pode ser compreendido pelo próprio empirismo" (LYOTARD, 1967, p. 15). Com isso, o empirismo não é capaz de se auto-sustentar. A própria contingência se encarrega de minar as suas bases, sendo este um dos argumentos básicos de Husserl na sua crítica contra o relativismo.

No psicologismo, especificamente, não se estabelece exata diferenciação no caso, por exemplo, da matemática - entre os estados psicofísicos que acompanham o raciocínio e as operações de raciocínio propriamente ditas. Husserl não aceita tal "obscuridade". Segundo ele, há uma "objetividade ideal" no 
raciocínio matemático verdadeiro, que está sujeita a condições lógicas e não factuais. Um triângulo "possui uma essência constituída por todos os predicados cuja hipotética supressão arrastaria a supressão do próprio triângulo..." (LYOTARD, 1967, p. 17).

A teoria husserliana da essência não se limita ao âmbito dos objetos matemáticos. Ela estende-se também ao "terreno favorito do empirismo": a percepção. A tese básica da eidética husserliana pode ser resumida da seguinte forma: é a consciência da impossibilidade que revela a essência. Lyotard nos apresenta como exemplo o juízo: "O muro é amarelo". Nele apresenta-se o objeto "cor". Como aceder fenomenologicamente à essência (ao eidos) ${ }^{10}$ deste objeto? Através do método da variação imaginária, método capaz de nos conduzir à consciência da impossibilidade do objeto. Quando, pela imaginação, tentamos apreender o objeto cor independentemente da superfície que the serve de suporte, tomamos consciência de que isso não é possível, "porque uma cor separada do espaço em que se nos apresenta é impensável" (LYOTARD, 1967, p. 17). O predicado extensão é, portanto, essencial ao objeto cor. Torna-se importante ressaltar que os limites aos quais a imaginação deve se ater são fixados "pelas coisas mesmas" e não pela consciência subjetiva em seu nível empírico.

A variação eidética deve se direcionar apenas ao vivido, isto é, à evidência atual na relação com o objeto. $O$ que permanece invariante ao final do processo constitui a essência (eidos) do objeto: "Experimenta-se, pois, a essência como uma intuição vivida [...]; a essência é apenas aquilo em que própria coisa se me revelou numa doação originária" (LYOTARD, 1967, p. 18).

O que se pode diferenciar em relação à ideia da "coisa mesma" da fenomenologia e as coisas que são encontradas a todo momento no mundo? 0 fato é que, na atitude fenomenológica, diante dos objetos, está em jogo uma espécie de suspensão do juízo quanto à realidade, enquanto "posição de existência" destes objetos. Em oposição, a atitude natural, própria do senso comum e também da ciência, caracteriza-se por uma espécie de aceitação da realidade factual das coisas, independentemente da percepção imediata que delas

\footnotetext{
${ }^{10} \mathrm{Na}$ raiz dos múltiplos significados da palavra eidos, segundo Ferrater Mora, encontra-se a noção de "aspecto". O eidos de algo corresponde ao seu "aspecto essencial", que integra a realidade do que se mostra e ao mesmo tempo sua inteligibilidade. No eidos, conjugam-se, portanto, o real e o conceitual (FERRATER MORA, 1964, p. 504).
} 
se pode ter. Através da redução fenomenológica, Husserl põe "entre parênteses" a "realidade" do mundo, transformando-o em fenômeno de consciência. A realidade do eu empírico, assim como a das coisas, é posta entre parênteses com a redução. O que subsiste fora do parêntese é o eu transcendental e o seu correlato objetivo, a coisa mesma, enquanto conteúdo intencional da consciência.

Face ao objeto, o eu puro ganha, em Husserl, uma nítida preponderância. 0 exemplo de uma análise eidética que contempla a "região coisa" e a "região consciência" pode esclarecer-nos esta afirmação. Uma árvore se mostra à percepção num fluxo incessante de perfis, que sucessivamente vão compondo a unidade objeto. O acesso perceptivo à arvore é, a cada vez, "unilateral". A "árvore total" não corresponde a uma "percepção total" do objeto. A percepção empírica é sempre parcial e necessariamente incompleta. $O$ dado perceptivo está sempre aberto ao que Lyotard chama de horizontes de indeterminação. A coisa não pode nunca se dar como um absoluto, porque na correlação entre a coisa e a percepção empírica está em jogo algo de inesgotável.

Dessa maneira, pela epochét1 fenomenológica, reduzo o meu eu natural e humano e a minha vida psíquica ao meu eu transcendental, ou o campo da autoexperiência transcendental fenomenológica. Tal eu, desta forma compreendido como "depurado", torna-se apenas concebível na sua relação intencional com o "objeto", o qual também já não é um objeto mundano, existente no sentido vulgar da palavra, mas um "objeto" puramente como "conteúdo intencional". Um objeto que é uma idealidade pura meramente significada, desprovido de qualquer caráter psicológico, é descrito em $A$ ideia da fenomenologia da seguinte maneira:

Ao encetar a crítica do conhecimento, importa, pois, adjudicar o índice da questionabilidade a todo o mundo, à natureza física e psíquica e, por fim, também ao próprio eu humano, juntamente com todas as ciências que se referem a estas objectalidades. A sua existência e a sua validade ficam por decidir (HUSSERL, 1986, p. 53).

\footnotetext{
${ }^{11}$ Epoché, no sentido fenomenológico, visa a "colocar entre parênteses" a crença em toda realidade temporal e espacial, isto é, em toda a transcendência. Isto quer dizer que não devemos fazer juízo algum sobre o mundo e tudo aquilo que nele se inclui, até mesmo as mais convincentes evidências científicas, uma vez que as ciências naturais se alimentam deste mundo empírico. Husserl irá introduzi-la não como instrumento de uma atitude cética, mas de depuração em busca de um radicalismo particularmente reflexo em direção às evidências apodíticas.
} 
Husserl continua nestes termos:

[...] em nossas afirmações fundamentais nada pressuporemos, nem sequer o conceito de filosofia, e assim queremos ir fazendo adiante. A epoché filosófica, que nos propusemos praticar, deve consistir, formulando-a expressamente, em nos abstermos por completo de julgar acerca das doutrinas de qualquer filosofia anterior e em levar a cabo todas as nossas descrições no âmbito desta abstenção (HUSSERL apud ZILLES, 2002, p. 22).

Em suma, tudo o que transcende a esfera imanente da consciência deve levar o rigor da criticidade e questionabilidade. Com isso, a existência do mundo, dos objetos, das ciências etc. é colocada "fora de juízo", porque carece do caráter de evidência absoluta, uma vez que suas afirmações vão além do que é imanente e seguro, do ponto de vista de uma fundamentação rigorosa do conhecimento.

Posto isso, vemos que o que é "colocado entre parênteses" não é negado, mas perde o caráter de absoluto e inquestionável e de validade, que lhe é atribuído na atitude natural e passa a valer como "fenômeno da consciência". Na atitude fenomenológica propiciada pela epoché, o modo de visão do mundo sofre uma transformação radical: deixa-se de aceitar resolutamente a evidência da existência empírica das coisas e, por conseguinte, deixa-se de lidar, prioritariamente, com o mundo físico (objetos espaço-temporais), passando-se a lidar com o "mundo da consciência", formado pelas vivências do sujeito.

Com isso, a epoché constitui-se, na filosofia de Husserl, o primeiro passo do método fenomenológico, ou seja, ela reflete a mudança de atitude necessária para o empreendimento proposto por ele, qual seja, a migração da atitude natural para a atitude fenomenológica. Tal caminho metodológico escolhido pelo filósofo alemão vem ratificar seu desejo de fundamentação absoluta, pois, se o que está em questão é o conhecimento, uma ciência não pode usar como fundamento aquilo que pretende investigar.

A ciência rigorosa que Husserl almeja construir exige, naturalmente, que nenhum conhecimento seja considerado de antemão. Evidentemente, no entanto, é de se supor que o pai da fenomenologia estabeleça algum conhecimento como sustentáculo inquestionável, a partir do qual ele edifique o seu pensamento reconstrutivo, sob o risco de recair permanentemente num círculo de regressão infinita. Segundo Husserl, o próprio exercício da epoché oferece como resultado 
este ponto de partida. A partir desta suspensão metodológica, "resiste" algo que é evidente e inquestionável e que remonta à reflexão cartesiana: a cogitatio.

Atinge-se, assim, um "ego cogito" verdadeiramente radical, só inteligível na sua explicitação plena "ego cogito cogitatum". Descartes chegara também a um "ego cogito" que prescindia do corpo, mas o seu "ego", apesar de incorpóreo salienta Husserl - era ainda uma realidade substancial, concretamente existente, identificada com a alma. Por outras palavras, um eu natural ou mundano.

Outro conceito importante na fenomenologia husserliana é o de intencionalidade, e que, de certa forma, subsidia a importância da epoché. Husserl vai buscá-lo em Brentano, que o utilizou em sua obraPsicologia do ponto de vista empírico (Psychologie vom empirischen Standpunkt, de 1874), a fim de estabelecer a diferença entre os fenômenos físicos e os psíquicos. Nas vivências, a consciência é sempre consciência de alguma coisa e o objeto da vivência é sempre objeto para uma consciência. No nexo intencional, o objeto visado é chamado por Husserl de noema ao passo que o modo de visá-lo é chamado de noesis. Assim, como o noema é o "mediador" entre a noesis e o objeto, o objeto da vivência sempre transcende ao noema, caracterizando a impossibilidade, segundo Husserl, de se desconsiderar a relação intencional ou a intencionalidade.

Para ultrapassar, então, o "meio caminho" de Descartes, Husserl começa pelo absolutamente radical, numa apodicidade absoluta, pondo "entre parênteses" não só o corpo, mas o eu na sua radicalidade total, enquanto existente no mundo, e, com ele, todos os seus atos. Neste exercício radical da epoché, atingimos os fenômenos verdadeiramente puros, pois só levamos em consideração aquilo que nos é dado na pura imanência, e, portanto, com plena evidenciação.

Nem os preconceitos do próprio eu podem viciar esta intuição plenamente originária, pois tudo está posto "entre parênteses". O eu, assim depurado, é o eu puro, apto a conhecer sem vícios, como "expectador desinteressado" ou "imparcial", tudo o que se apresenta como é, ou melhor, tudo o que dele brota; trata-se agora do eu numa nova atitude oposta à natural, isto é, está em jogo o eu em atitude fenomenológica ou transcendental.

Dessa maneira, Husserl acreditava que se teria atingido o último fundamento que verificava todas as condições requeridas para a construção da filosofia rigorosa: aprioridade absoluta numa ausência radical de pressupostos, e evidência imediata, plenamente garantida, contra a intromissão de qualquer pressuposto: 
"Entro num mundo novo que Descartes não pôde explorar precisamente porque não exercitou a 'epoché' de um modo absolutamente radical" (HUSSERL apud FRAGATA, 1959, p. 67).

Portanto, Descartes construiu sobre o cogito num processo de aditamentos sucessivos; Husserl não terá mais que encerrar-se no seu cogito para explorar o que nele está contido, num processo descritivo e analítico. Resumindo em poucas palavras, Descartes investigou o que se conclui do cogito; Husserl, o que nele se inclui. Assim, compreendemos melhor o sentido profundo da epoché husserliana. Por meio dela, não se renuncia propriamente ao mundo, mas apenas, à maneira ingênua de o considerar:

Em vez de possuir o mundo de um modo ingênuo e de propor questões ingênuas sobre $o$ mundo, propomos agora novas questões sobre o mundo que puramente em nós, e primeiro de mim e em mim, adquiriu sentido e valor; em mim, notemo-lo bem, como eu transcendental (HUSSERL apud FRAGATA, 1959, p. 81).

Assim, podemos compreender a fenomenologia proposta por Husserl como: "disciplina puramente descritiva que explora, pela intuição pura, o campo da consciência transcendentalmente pura" (XIRAU, 1941, p. 44).

Entretanto, Heidegger visa a trazer à luz o ser, pesquisando o seu sentido enquanto desvelamento e manifestação. Para ele, o traço fundamental da fenomenologia, "voltar-se para as coisas mesmas" ("zu den Sachen selbst'), é a recuperação da atitude básica dos pensadores gregos: abrir-se para a experiência do ser dos entes em seu desvelamento e ocultação (HEIDEGGER, 1973, p. 498). É necessária uma análise ontológica e hermenêutica (interpretativa, de compreensão de sentido) que revele "o ente que nós somos", o ser-aí (o Dasein), que deve substituir as noções de "sujeito" ou "eu", devido ao sentido de ser simplesmente subsistente que estes termos adquiriram na filosofia da consciência e da subjetividade do período moderno, incluindo aí a própria concepção husserliana de "sujeito".

De fato, no âmbito da analítica existencial de Ser e tempo, evocando a história do esquecimento do ser e das consolidações das noções de "sujeito" e "eu" e, consequentemente, de nossas verdades possivelmente cristalizadas, as quais muitas vezes se confundem com a própria história do pensamento humano, ou seja, com a própria história da filosofia - mas não só! -, uma vez que toda e 
qualquer situação ou contexto humanos já implicarem necessariamente a tarefa de uma interpretação, pela razão de eles jazerem numa compreensão fundamental do ser, Heidegger acaba dando os passos decisivos rumo a uma fenomenologia hermenêutica.

\section{Heidegger: os passos decisivos em vista da fenomenologia hermenêutica}

Como vimos, o grande interesse de Heidegger, interesse esse que o motivou a deixar o curso de teologia para ingressar na filosofia, foi a questão sobre o sentido do ser. Ser e tempo aborda a questão do ser por pretensos caminhos ditos radicalmente diferentes daqueles percorridos até então pela tradição, ou seja, sem se deter apenas na pergunta "o que é o ser?", mas, sim, "a respeito de seu sentido". O objetivo da ontologia, de determinar a quididade dos entes, transforma-se, então, numa questão hermenêutica. $O$ método empregado nesse questionamento ontológico em Ser e tempo é denominado por Heidegger como "fenomenologia hermenêutica". Segundo ele, a fenomenologia, herdada de seu mestre Husserl, visa dirigir-se "às coisas elas mesmas". Esse "às coisas mesmas" nada tem a ver com a coisa "em si" da tradição, refere-se a um retorno "às coisas mesmas" tal como elas aparecem e se dão à consciência. Porém, diferentemente de Husserl, a fenomenologia de Heidegger não se reduz apenas à descrição das estruturas do "ser-homem"; elabora, de forma radical, este "ser-homem" como e enquanto "ser-aí" (Dasein), abandonando qualquer determinação do homem como sujeito psicológico ou transcendental. Para Heidegger, o traço fundamental da fenomenologia, "voltar-se para as coisas mesmas", é a recuperação da atitude básica dos pensadores gregos: abrir-se para a experiência do ser dos entes em seu desvelamento e ocultação (HEIDEGGER, 1969, p. 33-80). Além disso, o filósofo deixa claro que, embora a expressão "fenomenologia" se refira a um conceito de método, não se trata da noção corrente de método usualmente empregada nas ciências, aquela de um artifício técnico usado como meio para alcançar um fim. Segundo ele, fenomenologia e ontologia não são separáveis e aquela não deve ser entendida como mais um "ponto de vista" ou uma "corrente" filosófica (HEIDEGGER, 2006, p. 65-66). 
Para melhor compreendermos o que Heidegger visualizou na obra Investigações lógicas, de Husserl, como um despertar para a, historicamente suprimida, experiência grega sobre o pensar o ser, recorremos aqui às suas próprias palavras em Meu caminho para a fenomenologia: "A distinção que Husserl aí constrói entre intuição sensível e categorial revelou-me seu alcance para a determinação do 'significado múltiplo do ente"' (HEIDEGGER, 1973, p. 497). Diferentemente da compreensão corrente na esteira do pensamento tradicional que, por intuição, entende o abordar imediato, retilíneo e sem intermediações de um ente qualquer, e que ganha com o neokantismo uma roupagem psicologista conceitual dos elementos a priori possibilitadores do conhecimento, Husserl, em oposição, realça a originariedade da intuição em relação à conceitualidade.

No último seminário de que participou antes de sua morte, o Seminário em Zähringen, no ano de 1973, Heidegger inicia respondendo a uma pergunta formulada pelo filósofo francês Jean Beaufret (1907-1982) que versa sobre a possibilidade da identificação da questão sobre o ser já em Husserl. Segundo Ser e tempo, numa perspectiva mais radical, não poder-se-ia afirmar que seu exímio professor e mestre iniciador na filosofia fenomenológica já havia, previamente, se ocupado com tal questão. No entanto, no capítulo intitulado "Sensibilidade e entendimento" das Investigações lógicas, teria marcado uma significativa aproximação com esta questão quando, segundo Heidegger, Husserl explicita a intuição categorial, aspecto que Heidegger considera o ponto fundamental do pensamento husserliano para a questão do ser (HEIDEGGER, 2009, p. 66-70). Husserl teria partido da intuição sensível, fazendo-se necessário um maior clareamento das bases da formulação husserliana. Segundo Heidegger, na determinação do que é a intuição sensível, Husserl teria partido da hylé, ou seja, do que nos afeta sensivelmente, a saber, os dados sensoriais. Destarte, apareceria o objeto, mas não como dado na impressão sensível, já que a objetividade do objeto não pode ser percebida sensivelmente, pelo fato de que, se o objeto é notado enquanto tal, não resulta da intuição sensível, mas da consciência que o constitui enquanto tal em um ato intencional. Com efeito, para a tradição ocidental, um objeto é uma coisa, e uma coisa é uma substância, sendo substância na filosofia kantiana uma categoria do entendimento. Por conseguinte, para Kant, o conhecimento é um trabalho realizado pelo entendimento, no qual se procede à síntese das representações e à aplicação das categorias para obtenção do 
conceito. Segundo Heidegger, Husserl recoloca a concepção kantiana de forma ${ }^{12}$ de que a categoria seja antes de mais nada uma forma.

Neste modo de conceber a intuição categorial, torna-se presente em si mesma como dada em um ato de intuição, diretamente acessível a esta. Heidegger dá o exemplo de um tinteiro em que, se é possível ver o tinteiro, o mesmo não acontece com a sua substancialidade. Contudo, a substancialidade deve ser vista sem o que não seria possível ver o tinteiro. Onde se encontra, pois, a substancialidade do tinteiro? A substancialidade do tinteiro encontrar-se-ia presente no excedente (Überschuss).

Husserl (1992, p. 101) lança mão, em suas reflexões, da aristotélica noção de substância (ousía), como "categoria primeira" e, no exemplo anterior dado por Heidegger, apontamos que o que este chama de "excedente de significação", o "ser tinteiro" do tinteiro, continua subliminarmente subentendido, quando olhamos para o tinteiro. Notamos que o "ser tinteiro" do tinteiro, em sua ousía, não tem a mesma forma de percepção do tinteiro propriamente dito, mas, ainda assim, torna-se presente, pois, sem o qual, nada se veria. Para tornar mais clara a distinção entre o sensível e o categorial, vejamos o que Husserl diz em Investigações lógicas.

Posso ver a cor, mas não o ser-colorido. Posso sentir a maciez, mas não o ser-macio. Podemos ouvir o som, mas não o sersonoro. O ser não é nada dentro do objeto, nenhuma de suas partes, nenhum momento a ele inerente, nenhuma qualidade ou intensidade, como também nenhuma figura, nem absolutamente nenhuma forma interna, nenhuma característica constitutiva, como quer que seja concebida. Mas o ser também não é nada de aderente ao objeto, assim como não é uma característica real interna, não é também uma característica real externa e por isso não é absolutamente nenhuma "característica", no sentido de uma característica real (HUSSERL, 1992, p. 105).

Ou ainda, segundo o próprio Heidegger, no Seminário em Zähringen:

[...] o "é" - pelo qual eu constato a presença do tinteiro como objeto ou substância - é em excesso entre as afecções sensíveis; com efeito, o "é" não está junto das afecções sensíveis; ele é visto

\footnotetext{
$12 \mathrm{Na}$ dissertação de 1770, Kant procede à distinção entre matéria e forma: "À representação pertence, em primeiro lugar, alguma coisa que se pode chamar matéria, que é a sensação, e, em segundo lugar, aquilo que se pode chamar de forma ou espécie das coisas sensíveis, que serve para coordenar, por meio de certa lei natural da alma, as várias coisas que impressionamos sentidos" (De mundi sensibilis et intelligibilis forma et rationel) (KANT, 1983). Esta distinção entre matéria e forma foi o ponto de partida de toda a filosofia kantiana, mas ele nunca alterou o significado de forma que continuou sendo a relação ou o conjunto de relações.
} 
- mesmo que visto de outro modo que aquilo que é visível e para que assim seja visto é necessário que seja dado. Para que assim seja "visto", é necessário que ele seja dado (HEIDEGGER apud MEDEIROS, 2009, p. 332).

Com isso, conforme entende Heidegger, o categorial é dado do mesmo modo que o sensível. Tal como é possível ter intuições sensíveis, também o é ter intuições categoriais e, para que se intua algo, esse algo tem de estar ele mesmo presente. Ora, se na intuição sensível os dados sensoriais se tornam presentes, analogamente, na intuição categorial, o que se torna presente e passível de ser intencionado e percebido de modo direto é o próprio ser que é dado de modo imediato.

Assim, se, em Kant, as categorias são os modos pelos quais se manifesta a atividade do entendimento, através da ordenação das diversas representações numa representação comum, ou seja, o conceito, elemento que propicia o juízo, e o acesso às categorias só poderia ser feito via tábua dos juízos, não havendo no nível da sensibilidade possibilidade de tal acesso, com Husserl é possível ter acesso às categorias através de uma intuição. Se intuição significa tornar presente, no caso de Husserl, e diferentemente de Kant, não é ter presente algo que se situa ao nível do entendimento, resultado de uma dedução; ao contrário, o que se torna presente de modo imediato, sem recurso a nenhuma atividade do entendimento, é a categoria. Assim, segundo Heidegger, Husserl teria descoberto algo de decisivo: o ver, segundo dois tipos de visão: sendo uma do tipo sensível e outra do tipo categorial, pois, como afirma Heidegger: "[...] quando vejo este livro, vejo bem uma coisa substancial, sem que veja a substancialidade como vejo o livro. Ora, é a substancialidade que, na sua inaparência, permite ao que aparece aparecer" (HEIDEGGER apud MEDEIROS, 2009, p. 333).

Assim, como a questão que move Heidegger é a questão do ser e de seu sentido, a análise da intuição categorial de Husserl liberta o ser da posição à qual a tradição o "confinou", como dado na cópula do juízo, não sendo mais o resultado de uma operação levada a cabo pelo entendimento, fruto somente de uma operação lógica ou de uma predicação. Ao contrário, essa descoberta reorienta a possibilidade da indagação heideggeriana, pois o ser é dado de modo imediato e, como Heidegger tem por sua a questão fundamental de explicitar o que seja o ser e o seu sentido, a descoberta husserliana propicia a possibilidade de proceder a tal interrogação. O que Heidegger identificou, portanto, como o 
ponto fundamental da fenomenologia de Husserl consiste em nos ter colocado na presença do ser, o qual se torna fenomenalmente presente através da intuição categorial. Mas se, por um lado, esta descoberta foi decisiva, por outro, o filósofo da Floresta Negra sugere que seu mestre não teria levado o pensar fenomenológico às últimas consequências, na medida em que, tendo obtido o acesso ao ser, ele não se interrogou acerca de seu sentido. Tal "incompletude" se daria ainda por uma certa manutenção de uma visão entificadora e objetal do ser. Para Heidegger, o ser objeto remete para um modo de ser próprio dos entes simplesmente dados (Vorhandenheit), modo de ser que não é o mais originário, porquanto é um modo de ser derivado dos entes que, antes de mais nada, são utensílios (Zeuge) que o Dasein usa nas suas ocupações cotidianas. Em contrapartida, a analítica existencial desenvolvida em Ser e tempo irá evidenciar que, nas ocupações cotidianas, o ser-aí sempre já opera e lida com os entes de modos diversos a partir de uma circunvisão (Umsicht), reservando para isso o termo manualidade (Zuhandenheit) (HEIDEGGER, 2006, p. 115-120; STEINER, 2013, p. 128-129).

Com isso, Heidegger imprime um nível de maior radicalidade para a epoché husserliana, "suspendendo" a própria consciência do sujeito, nomeado anteriormente por Husserl como transcendental. Num texto de Roberto Novaes de Sá, intitulado "As influências da fenomenologia e do existencialismo na psicologia", podemos ler formulado assim: "A relação sujeito-objeto considerada a mais geral pela tradição é considerada por Heidegger como uma das possibilidades históricas de sentido da relação do homem com a coisa. O ser do homem é pura abertura de sentido, Dasein, ser-aí, existência, ser-no-mundo" (NOVAES DE SÁ, 2007, p. 319-338).

Assim, a intencionalidade, enquanto a propriedade fundamental da consciência de estar sempre dirigida para um objeto, é substituída pelo "cuidado" $(\text { Sorge })^{13}$, isto é, o Dasein é abertura através da qual se desvela o sentido dos entes que lhe vêm ao encontro no mundo. Com isso, há uma transição estrutural da fenomenologia, antes transcendental com Husserl e, a partir de então, hermenêutica fenomenológica, para Martin Heidegger.

\footnotetext{
${ }^{13} \mathrm{Na}$ edição brasileira de Sein und Zeit utiliza-se o termo "cura" para traduzir Sorge. Preferimos o termo "cuidado", amplamente utilizado pelos comentadores e tradutores de Heidegger.
} 
Ser e tempo, embora seja um projeto que não se concluiu (HEIDEGGER, 2006, p. 79-80), tal inflexão, representada, entre outras formas, pelo abandono dos termos "fenomenologia" e "hermenêutica", nunca foi reconhecida por Heidegger como um rompimento de trajetória do pensar, mas, sim, como uma continuidade. Num curso que se tornou célebre, intitulado Introdução à metafísica, ele escreve:

No tratado Ser e tempo a questão sobre o sentido do ser é posta e desenvolvida pela primeira vez na história da filosofia, COMO QUESTÃO, propriamente dita. Nele também se diz e fundamenta detalhadamente o que se entende por sentido (a saber, a manifestação do ser e não apenas do ente como tal; cf. Sein und Zeit, §§ 32, 44 e 56) (HEIDEGGER, 1969, p. 111).

Assim, considerando que, durante toda tradição, o ser sempre foi pensado a partir dos entes, Heidegger evidencia minuciosa e analiticamente aquele ente que lança a interrogação sobre o ser, o existente humano enquanto ser-aí (Dasein) como privilegiado no ato de colocar e sustentar a questão pelo sentido do ser (HEIDEGGER, 2006, p. 42). Por conseguinte, requereria deste ente que nós mesmos somos uma análise mais rigorosa quanto ao seu modo de ser, antes que se adentre na pesquisa ontológica que trata mais diretamente sobre o questionamento do sentido do ser.

O projeto original de Heidegger para Ser e tempo nunca foi, contudo, concluído pois as duas únicas seções publicadas tratam da analítica da existência humana. Contrariamente ao seu propósito, a obra acaba ganhando uma interpretação como tratado de ontologia fundamental e, enquanto tal, torna-se uma referência fundamental para as ciências humanas (STEINER, 2013, p. 120).

Ao designar como Dasein (ser-aí enquanto ser-no-mundo) o modo de ser deste ente que nós mesmos somos, aponta como diferença radical com relação aos entes que não têm este modo de ser o fato de que o homem é o ente que não possui uma essência anterior à existência. Outrossim, o que ele é, seu ser, está sempre em jogo no seu existir. O modo de ser dos entes não humanos é denominado como "ser simplesmente dado" (Vorhandenheit), porque o que eles são, o seu sentido, nunca está em jogo em seu devir temporal; enquanto que o modo de ser do homem é a "existência", o "ser-aí", o "ser-no-mundo". Heidegger entende que o ser-aí é uma possibilidade aberta, ou seja, é existindo que se é-aí 
como possibilidade de ser para as circunstâncias de um mundo e no constante exercício de existir nele (STEINER, 2013, p. 123).

Diferentemente da tradição e não facilmente perceptível, o ser-aí prescinde totalmente de um sujeito anterior que desenvolva seu modo de ser-no-mundo (Inder-Welt-sein). Ao contrário, ser sujeito, ou até mesmo a própria consciência intencional de Husserl, tem como condição de possibilidade o ser-aí, que acaba ganhando contornos historicamente constituídos desta ou daquela maneira. Notase, portanto, que ser-no-mundo é muito mais um modo de cuidar do que uma condição humanadada. Afinal, Heidegger põe sob epoché, inclusive, a pressuposição de uma subjetividade determinante da percepção dos fenômenos, para buscar no sentido do ser o que faria das coisas elas mesmas, sem ter que recorrer para tanto a uma "egologia".

\section{Considerações finais}

A partir da ontologia fundamental heideggeriana, cujo pano de fundo é a busca de um distanciamento crítico do pensamento da tradição, apresentamos de forma sucinta o pensamento do filósofo alemão que, buscando denunciar a partir de sua primeira e mais significativa obra Ser e tempo um eventual esquecimento da diferença ontológica entre ser e ente, esquecimento este fundante de uma crença em estruturas estáveis do ser, recoloca a questão do sentido do ser, questão esta que teria sido esquecida pela tradição, e tida por ele como a mais fundamental de todas as questões.

Tendo como pedra angular fundamental para sua inflexão do caminho teológico para a trajetória filosófica, as reflexões brentanianas sobre a multiplicidade do significado dos entes já tratadas em Aristóteles, Heidegger se vê arremessado ao encontro da questão sobre a determinação fundamental e unitária do ser que rege o ente em suas múltiplas significações. A atmosfera crítica à mentalidade positivista e aos preceitos neokantianos que imperavam em Friburgo no início do último século constitui-se como um importante ambiente filosófico influenciador dos primeiros passos do pensamento do ainda jovem Heidegger em direção ao mote reflexivo caracterizador de sua filosofia: a questão sobre o sentido do ser. 
O legado cartesiano que se sedimenta na modernidade e que "converte" o homem em sujeito, estruturando uma relação eminentemente binária deste sujeito com o mundo pautada nas clássicas dicotomias metafísicas se fundamenta, segundo Heidegger, no esquecimento da diferença ontológica operada pela tradição metafísica. Entretanto, compreender os elementos constitutivos da edificação teórica do filósofo alemão nos fez remontar o "caldo filosófico" do século XVIII e, neste sentido, revisitar Hume com a distinção e as relações entre impressões e ideias, bem como seus níveis de vividez e complexidades, bem como a influência do pensamento do filósofo inglês na estruturação do pensamento de Immanuel Kant, ao qual Heidegger vai se referir ainda nas primeiras linha de Ser e tempo como invocador do início de um despertar de um "sono dogmático" sobre os conceitos fundamentais da filosofia e da própria questão do ser. Neste sentido, o questionamento do empirismo inglês também ganha vigor com a releitura das categorias do espaço e do tempo por Kant como formas fundantes da percepção, defendendo que não nos seria possível buscar um eventual conhecimento da coisa em si, visto que nenhuma experiência humana estaria fora do campo fenomenológico da experiência espaço-temporal. Disso decorre a maior explicitação dos limites do entendimento sobre as experiências sensíveis e o consequente "salto" para o recurso do sujeito transcendental em Kant, fator este determinante para sua influência nas perspectivas transcendentais não só em Heidegger, mas como de seus predecessores Friedrich Schleiermacher, Wilhelm Dilthey e Edmund Husserl (STEINER, 2013, p. 113-115).

Heidegger chega a admitir que, ao final dos anos de 1920, Kant tornara-se um de seus principais interlocutores durante os anos que concebeu e desenvolveu o tratado Ser e tempo, tendo grande importância no nascimento da constatação de um necessário recuo crítico para uma dimensão mais originária do que a dimensão da representação, na qual desenvolve a analítica existencial do ser-aí enquanto ser-no-mundo, procurando, então, desfazer a compreensão da relação sujeito-objeto.

Gadamer sublinha em Verdade e método que a hermenêutica diltheyana, de reconhecida influência em Heidegger, emerge no bojo de uma "complementação" à crítica da razão pura mediante uma crítica da razão histórica, no intento de elucidar as categorias do mundo histórico subjacentes às ciências humanas 
(GADAMER, 2004 e 2007). O mundo histórico, assim, produz espontaneamente estruturas significativas que condicionam as ciências do espírito.

A leitura de Dilthey permite a Heidegger atribuir uma especial atenção ao tema da historicidade da compreensão, mas operando um deslocamento do nível psicológico para uma dimensão mais originária do questionamento ontológico. Realça o primado da experiência co-originária e co-constitutiva do ente que nós mesmos somos, cujo modo de ser enquanto ser-aí (Dasein), é a própria abertura descerradora de sentido de mundo, fundamento da esfera volitiva de um sujeito pensante, no uso de seus atributos cognitivos e regidos pela lógica imperativa da razão, filiando assim a historicidade na dimensão ontológica.

Como já dito, a influência da obra de Brentano sobre o autor das Investigações lógicas foi um fator decisivo, reconhecido por Heidegger, por exemplo, em Meu caminho para a fenomenologia, para a sua aproximação com o mestre Edmund Husserl nos primórdios de suas primeiras incursões fenomenológicas. Entretanto, a "disciplina puramente descritiva que explora, pela intuição pura, o campo da consciência transcendentalmente pura" (XIRAU, 1941, p. 44) em Husserl, na busca do "voltar-se para as coisas mesmas" ("zu den Sachen selbst') ganha em Heidegger o vigor de recuperação da atitude básica dos pensadores gregos, a saber, abrir-se para a experiência do ser dos entes em seu desvelamento e ocultação. As compreensões de "sujeito" ou "eu", substancializados na filosofia da consciência e da subjetividade do período moderno - incluindo aí a própria concepção husserliana de "sujeito" -, são substituídas pela análise ontológica e hermenêutica (interpretativa, de compreensão de sentido) que revele "o ente que nós mesmos somos", o ser-aí (Dasein). Diferentemente da compreensão hegemonicamente predominante na tradição metafísica e, não sendo substancializável, o ser-aí é a própria condição de possibilidade de mundo enquanto sentido de ser. Assim, muito embora Ser e tempo tenha se mostrado como um projeto inconcluso, Heidegger jamais concebeu tal inflexão como uma ruptura filosófica. Contudo, esta obra adquire estatudo de tratado de ontologia fundamental, tornando-se uma referência fundamental para as ciências humanas desde seu surgimento. 


\section{Referências}

DILTHEY, W. Introdução às ciências humanas: Tentativa de uma fundamentação para 0 estudo da sociedade e da história. Rio de Janeiro: Forense Universitária, 2010.

FERRATER MORA, J. Diccionario de filosofía. 2 vol.,5. ed. Buenos Aires: Sudamericana, 1964.

FRAGATA, J. A fenomenologia de Husserl. Braga: Livraria Cruz, 1959.

GADAMER, H.-G. Verdade e método l: Traços fundamentais de uma hermenêutica filosófica. 8. ed. Petrópolis e Bragança Paulista: Vozes e Edusf, 2007.

Verdade e método II: Complementos e índice. 2. ed. Petrópolis e Bragança Paulista: Vozes e Edusf, 2004.

Truth and method. 2. ed. rev., Londres e Nova lorque: Continuum, 2006.

GRONDIN, J. Introdução à hermenêutica filosófica. São Leopoldo: Unisinos, 1999.

HEIDEGGER, M. Ser e tempo.GA 2. Petrópolis e Bragança Paulista: Vozes e Edusf, 2006.

Sein und Zeit.GA 2.Frankfurt am Main: Vittorio Klostermann, 1977.

. Kant e o problema da metafísica. GA 3. Rio de Janeiro: Via Verita, 2019.

Klostermann, 1973.

Kant und das Problem der Metaphysik.GA 3.Frankfurt am Main: Vittorio .History of the concept of time.GA 20. Indianápolis: Indiana University Press, 1985.

Prolegomena zur Geschichte des Zeitbegriffs. GA 20. Vittorio Klostermann: Frankfurt am Main, 1979.

A essência da liberdade humana: introdução à filosofia.GA 31. Rio de Janeiro: Via Verita, 2012b.

Vom Wesen der menschlichen Freiheit. Einleitung in die Philosophie. GA 31. Frankfurt am Main: Vittorio Vittorio Klostermann,1994.

.Introdução à metafísica.GA 40. Rio de janeiro: Tempo Brasileiro, 1969.

1983.

.Einführung in die Metaphysik. GA 40.Frankfurt am Main: Vittorio Klostermann,

. Ontologia (hermenêutica da faticidade).GA 63.Petrópolis: Vozes, 2012a.

- Ontologie (Hermeneutik der Faktizität). GA 63.Frankfurt am Main: Vittorio Vittorio Klostermann, 1995.

Meu caminho para a fenomenologia. São Paulo: Abril Cultural, 1973.

.Tiempo e historia. Madri: Trotta, 2009. 
HUSSERL, E. Investigações lógicas. Sexta investigação (Elementos de uma elucidação fenomenológica do conhecimento). 5. ed. São Paulo: Nova Cultural, 1992.

.A ideia da fenomenologia. Lisboa: Edições 70, 1986.

.ldeas relativas a una fenomenología pura y una filosofía fenomenológica. 2. ed.

México e Buenos Aires: Fondo de Cultura Económica, 1962.

KANT, I. Crítica da razão pura. 5. ed. Lisboa: Fundação Calouste Gulbenkian, 2001.

.Crítica da razão prática. Lisboa: Edições 70, 2008.

Acerca do primeiro fundamento da diferença das regiões do espaço. In: Textos pré-críticos. Porto: Rés, p. 165-174, 1983.

KIRCHNER, R. A temporalidade da presença: a elaboração heideggeriana do conceito de tempo. Rio de Janeiro: Instituto de Filosofia e Ciências Sociais (UFRJ), 2007.

A fundamental diferença entre o conceito de tempo na ciência histórica e na física: interpretação de um texto heideggeriano. Veritas, v. 57, n. 1, p. 128-142, 2012.

Da ontologia fundamental à pergunta pela essência do ser-aí humano, in: GIL FILHO, S.F.; SILVA, M.A.S. da; GARCIA, R.R. (org.). Ernst Cassirer: geografia e filosofia. Curitiba: Programa de Pós-Graduação em Geografia (UFPR), p. 279-307, 2019.

LYOTARD, J.-F. A fenomenologia. São Paulo: Saber Atual, 1967.

MEDEIROS, T.T.Q. de. Seminar in Zähringen: aspectos da crítica heideggeriana à fenomenologia de Husserl, in: Intuitio, v. 2, n. 3, p. 330-346, 2009.

MORAES, F. de. Heidegger leitor de Aristóteles: a questão do ser. Aufklärung, v. 4, edição especial, p. 37-46, 2017.

NASCIMENTO, C.L. do. Cuidado e educação: uma abordagem fenomenológicohermenêutica. Rio de Janeiro: Via Verita, 2019.

NOVAES DE SÁ, R. As influências da fenomenologia e do existencialismo na psicologia. In: JACÓ-VILELA, A.M.; FERREIRA, A.A.L.; PORTUGAL, F.T. (org.). História da psicologia: rumos e percursos. Rio de Janeiro: Nau, p. 319-338, 2007.

NUNES, B. Passagem para o poético. São Paulo: Ática, 1992.

PALMER, R.E. Hermenêutica. Lisboa: Edições 70, 1986.

PEREIRA, A. Hume e Kant a respeito do inato. Revista de Iniciação Científica da FFC, v. 4, n. 3, p. 193-204, 2004.

PÖGGELER, O. A via do pensamento de Martin Heidegger. Lisboa: Instituto Piaget, 2001.

RICOEUR, P. Interpretação e ideologias. Rio de Janeiro: Francisco Alves, 1977.

SCHLEIERMACHER, F. Hermenêutica: arte e técnica da interpretação. Petrópolis: Vozes, 2004.

STEINER, G. Martin Heidegger. Lisboa: Relógio D’Água, 2013. 
R. Kirchner; C. L. do Nascimento

XIRAU, J. La filosofía de Husserl: Una introducción a la fenomenología. Buenos Aires: Losada, 1941.

ZILLES, U. A crise da humanidade europeia e a filosofia. Porto Alegre: EDIPUCRS, 2002.

RECEBIDO: $23 / 07 / 2020$

RECEIVED: $23 / 07 / 2020$

Aprovado: 25/05/2021

Approved: 25/05/2021 